\title{
CONSTITUCIONALISMO E COLONIALIDADE: NOVO CONSTITUCIONALISMO LATINO-AMERICANO E O DIREITO DA PALAVRA DA TRADIÇÃO AFRICANA COMO RESISTÊNCIA NA MODERNIDADE
}

\author{
MARIA SUELI RODRIGUES DE SOUSA ${ }^{1}$ \\ UFPI, BRASIL \\ http://orcid.org/0000-0003-4611-2262
}

\begin{abstract}
RESUMO: O objeto discutido é a unidade da abstração constitucional e a pluralidade do mundo empírico das subalternidades ${ }^{2}$ produzidas pela colonialidade, tendo como questão orientadora: como enfrentar a unicidade do projeto modernidade/colonialidade para expressar a pluralidade no constitucionalismo dos povos subalternizados? Com o pressuposto de que o enfrentamento ocorre com a revelação do que foi ocultado e valorização do inferiorizado. A discussão foi feita sob a visão de que o modelo eurocêntrico se realiza ontológica e epistemologicamente. Portanto, o enfrentamento deve atingir essas dimensões. $O$ estudo foi realizado no âmbito de um projeto sobre constitucionalismo brasileiro por meio de análise bibliográfica com levantamento em mapas de associação de ideias sob orientação da modernidade como resistência. E como resultado do estudo foi produzida uma narrativa analítica sobre racialização do projeto modernidade/colonialidade e indicação das resistências dos povos inferiorizados na América Latina e na África a partir de suas matrizes ontológicas e epistemológicas como constitucionalismo e etnodireito.
\end{abstract}

PALAVRAS-CHAVE: decolonialidade, modernidade, constitucionalismo latino-americano, juridicidade africana.

ABSTRACT: The object discussed is the unity of constitutional abstraction and the plurality of the empirical world of the subalternities produced by coloniality, having as a guiding question: how to face the uniqueness of the modernity / coloniality project to express the plurality in the constitutionalism of subalternized peoples? With the assumption that the confrontation occurs with the revelation of what was hidden and valorization of the inferior. The discussion was made under the view that the Eurocentric model is carried out ontologically and epistemologically, so the confrontation must reach dimensions. The study was carried out as part of a project on Brazilian constitutionalism through bibliographic analysis with a survey of association maps of ideas under the guidance of modernity as resistance. And as a result of the study, an analytical narrative about the racialization of the modernity / coloniality project and indication of the resistance of the inferiorized peoples in Latin America and Africa was produced from their ontological and epistemological matrices such as constitutionalism and ethno-law.

KEYWORDS: decoloniality, modernity, Latin American constitutionalism, African legality.

\footnotetext{
${ }^{1}$ Professora associada da Universidade Federal do Piauí, lotada no Departamento de Ciências Jurídicas DCJ, no Programa de Pós-Graduação em Sociologia, no Programa de Pós Graduação em Gestão Pública, no Núcleo de Pesquisa sobre Africanidades e Afrodescendência - IFARADÁ e do grupo de pesquisa direitos humanos e cidadania - DiHuCi. E-mail: mariasuelirs@ufpi.edu.br

${ }^{2}$ Spivak (2010) considera que o termo subalterno não significa a pessoa oprimida, mas tem o sentido de quem não tem oportunidade de se expressar, de ter o seu lugar reconhecido. O subalterno é silenciado, o que não tem o poder de falar, aquele que sempre é objeto de estudo e nunca o sujeito.

SOUSA, Maria Sueli Rodrigues de. Constitucionalismo e colonialidade: novo constitucionalismo latino-americano e o direito da palavra da tradição africana como resistência na modernidade. Espaço Ameríndio, Porto Alegre, v. 14, n. 2, p. 411-445, jul./dez. 2020.
} 


\section{Introdução}

A ideia de constitucionalismo - enquanto narrativa que permeia os discursos tanto dos manuais de direito quanto do que equivocadamente é chamado de doutrina - não faz parte do universo do direito ocidental desde sempre. O direito passou a ser visto como constitucionalismo - e vice-versa - após o final da segunda guerra mundial, quando se instaura uma nova ordem como poder sobre as nações, sendo o controle destas conformado pelos direitos humanos. Em outras palavras, a ordem mundial que responde como Organizações das Nações Unidas, a ONU, passa a controlar as nações pelo cumprimento ou descumprimento dos direitos humanos, criando a demanda de positivar os direitos humanos nas constituições. Tal atribuição está de acordo com a teoria de Kelsen (1997) sobre o direito validado pela hierarquia da constituição, o que tornou o tema mais visível e com mais ampla viabilidade.

A visibilidade ao tema fez emergir reflexões diversas sobre o fenômeno, mas sempre com a mesma perspectiva: de fazer parte da racionalidade ocidental com origem nas constituições dos Estados Unidos da América e da França, estruturado na ideia de separação dos poderes, de limitação do poder soberano sobre os pertencentes ao pacto de nação. Como se pode ver, o fenômeno é recente, estendendo-se no máximo à Inglaterra, com sua Carta Magna de 1.215 limitado o poder soberano e protegendo o indivíduo.

Mas se perguntarmos "o que é o indivíduo?", qualquer reflexão feita para responder à questão será por meio de uma visão ontológica que nos faz enxergar o ser que se busca ser nas dinâmicas sociais vitais traçadas nos itinerários percorridos. E tratar de objetivo de vida significa ver direito/constituição, moral, ética, religião e todos os corpos normativos como meio e não como fim, sendo o fim definido pelo ser que se crê ser e/ou que se busca ser. Vale afirmar que este ser que orienta o presente é o que atua como universal, como verdade absoluta e que faz parte do projeto de se afirmar como visão única de mundo. É a primeira e única experiência de que se tem notícia no âmbito dos registros sobre nossa espécie sobre uma cultura se assumir como única civilização, cultura, política e economia.

A ideia que enraíza o mundo em que vivemos é a de ser humano hierarquicamente superior às outras vidas a que chama de natureza, que se considera separado da natureza, com a finalidade de produzir/acumular/consumir riquezas com o domínio das outras vidas. E o que o habilitou para ser este ser foi a pretensa consciência de ser racional que, segundo Hegel (1992), evoluiu da percepção do mundo pelos sentidos, de ter consciência, de ter consciência de si e de ter consciência para si. Segundo este autor, o itinerário percorrido foi o de libertação da relação com a religião. A cadeia evolutiva que Hegel apresenta começa na religião da natureza, passa pela religião da arte e finalmente alcança a religião manifesta. Nesta escala, primeira categoria corresponde à consciência; a segunda, à condição de consciência de si; e apenas a terceira possibilita a consciência para si. Na visão do autor, a condição de humano só é atingida com a religião manifesta, maturada 
com a consciência de que o que diferencia o ser humano é sua capacidade racional, que inicialmente é percebido como espírito, mas cuja ciência faz chegar à verdade pretensamente universal da fundamentação da superioridade humana na capacidade racional.

A base religiosa que também vira filosófica, cientifica, histórica e tecnológica para criar a superioridade humana se funda, segundo Hegel (1992), na visão de que só é racional a espécie humana! Uma visão que tem amparo na religião mediante a construção da narrativa segundo a qual o ser humano tem espírito, responsável por eternizá-lo, pois quando termina sua vida terrena, sua existência no mundo espiritual junto ao seu sagrado de quem ele é a imagem e semelhança continua - caso não tenha feito, no exercício do livre arbítrio, aquilo que está de acordo com os desígnios religiosos, ele irá para o lugar oposto.

Hegel (1992) afirma que a ciência libertou o ser humano destes desígnios, mas sabemos que a afirmação carece de empiria para comprová-la, considerando que a base filosófica nunca enfrentou a narrativa de que o sagrado da humanidade é o próprio ser humano ou sua razão. E este sagrado, Deus, permanece como fonte dos valores que orientam a humanidade e que se fez como hegemonia. E quando não é o sagrado cristão, é um sagrado também humano e/ou de um outro mundo espiritual, o que cumpre o mesmo propósito de liberar para produzir riquezas na materialidade da terra.

A relação com um sagrado pai do ser humano habilita-o, no exercício do seu livre arbítrio, para intervir no planeta por meio do trabalho orientado pela ciência, no qual atua como se gestor fosse. Eis o nascedouro do paradigma do mundo do trabalho, em que o ser humano é livre para intervir no planeta sob orientação de produzir, acumular e consumir riquezas. E que guarda como modelo mental para orientar o seu ser uma espécie de tipo ideal weberiano ${ }^{3}$ com base em seu sagrado, que alimenta o ideal de ser perfeito, heroico, imortal e que sempre está muito distante do real, o que se move por um tempo linear em que o ser atua voltado para um futuro sempre inalcançável porque, quando atinge o pretendido, este já se modificou.

Para Hegel (1992), o que foi considerado espírito num momento, noutro, com o amparo da ciência, virou razão como verdade absoluta, que suporta todas as contestações. E se trata de qualificação restrita ao ser humano, que o mesmo só tem acesso a esta revelação por meio da ciência. $\mathrm{O}$ autor considera que o sagrado do cristianismo inicialmente foi apenas metafísico, o que impedia a intervenção no mundo a favor da espécie humana! A ciência fez o ser humano descobrir que o que ele tem de diferente em relação às outras espécies é a capacidade racional, considera restrita ao ser humano!

E o ser da espécie humana só se torna humano quando se conscientiza da sua superioridade, o que não ocorria com aqueles que

\footnotetext{
${ }^{3}$ Weber (2004) cria um modelo a que nomina de tipo ideal, o que serve para identificar o modelo/dever ser da modernidade: é indivíduo, que se constrói com a elevação da autoestima e faz sua subjetividade se ver como superior a tudo. Para isso é alimentado com artes de modo a se perceber como herói, imortal, focado num tempo inexistente, o futuro, alimentado pelo mito do amor romântico, que nuca se realiza.
} 
acreditavam que o seu sagrado era uma árvore, um rio, a terra, um outro animal! Estes não teriam descoberto sua superioridade! Não tinham descoberto sua condição humana. Portanto, não eram racionais. Como afirma Kakozi (2019), a luta dos povos africanos é a luta pela razão!

Uma empiria que vem cada vez mais afirmando a racionalidade do que foi chamado de irracional é o fato de buscarem solução para a crise da modernidade exatamente em saberes tradicionais dos povos africanos e povos originários da Abya Yala, a que foi chamada de América, e na Índia! É o bem viver e a filosofia indiana para enfrentar a hierarquia do ser humano com relação às outras vidas e efetivamente atuar na crise ambiental como crise da racionalidade moderna! E filosofias africanas, como ubuntu, para enfrentar as crises sociais ocidentais: seja a justiça restaurativa para enfrentar o punitivismo do direito ocidental, seja a constelação familiar para enfrentar os excessos do individualismo e sua incapacidade de se colocar no lugar da outra pessoa com quem convive!

Apesar da busca das racionalidades africana, indiana e abya yala para enfrentar a crise da modernidade, não há uma iniciativa para construir outra ideia de produção de conhecimento. Continuamos presos a uma visão de superioridade do ser humano, de um ser apartado da sua condição de natureza, arrogante ao abusar das outras vidas como se fosse seu gestor nato, sempre infeliz porque nunca está nem próximo do tipo ideal que ocupa seu projeto de futuro.

Diante disso, é possível afirmar que a constituição que constitui uma comunidade política voltada para ser este ser, está voltada para conformar uma sociedade produtora/acumuladora/consumidora de riquezas. No sistema-mundo, como afirma Wallerstein (1974), a forma que temos para resistir está no campo epistemológico e operacional, não comportando pensar no ser que somos, porque isso é tido como único, como verdade absoluta afirmada permanentemente pela superioridade da ciência como único conhecimento verdadeiro.

Mas a crise não para de crescer e a crise ambiental é o motor de tudo! O que exige repensar que ser é este: que se alimenta para alcançar estatísticas que o planeta não suporta; que não tem limites para acumular riquezas; que resume sua felicidade em valores individuais como se não pertencesse a uma comunidade; que não é solidário com sua espécie; que transformou solidariedade em cumprimento de regras; que é arrogante ao extremo, ao ponto de portar-se como gestor das vidas, do planeta e do universo!

Refletir sobre a crise fez fortalecer resistências de ontologias que foram consideradas como não civilização, não cultura, não política, que foram atacadas e negadas, com tentativas permanentes de apagamento de suas existências. Estas vozes emergiram em enfrentamentos vários e fizeram ver que as outras vidas não são objetos e patrimônios do ser humano, mas são vidas que se mantêm com solidariedade entre a espécie, exercem poder para se firmar num determinado território, adotam estratégias de defesa para naquele território permanecer - como as abelhas, as formigas, as ovelhas, os pássaros e todas as vidas chamadas de natureza. Portanto, são grupos que se associam para ocupar um determinado território e elaboram estratégias de defesa para garantir 
sua territorialidade - o que faz lembrar comunidade política, pertencimento territorial como sentimento e permite refletir sobre as origens desses aspectos como restritos ao ser humano da experiência europeia.

A vida não é invenção europeia e todas as vidas elegem formas de se proteger, o que permite vislumbrar comunidades políticas em todos os tempos e para todas as vidas - como a constituição do grupo de humanos neste território que já foi chamado de Pindorama, na Abya Yala, na África, na Ásia! Mas também comunidades de abelhas, formigas, ovelhas, árvores, ou seja, todas as vidas! Portanto a formação de comunidades políticas para firmar o seu poder sobre o território não é fenômeno restrito à capacidade que os europeus detinham, mas está presente em todas as vidas que também demonstram habilidades, que faz perceber nestes uma capacidade racional como algo que orienta planejar o que será feito para atingir o resultado pretendido.

A comunidade política que se organiza num território que considera seu e elabora estratégias de defesa para garantir o pretendido e foi nominada como constitucionalismo, efetivamente, não é descoberta europeia nem restrita aos humanos! Sempre existiu! É estratégia de proteção à vida! Massumi (2017), ao discutir o que os animais nos ensinam sobre política, ao analisar a capacidade animal de diferenciar um ato de brincadeira de uma atitude de violência, afirma a atuação política dos animais com pensamento e não apenas comportamento, dotados de "capacidades sobre as quais nós, animais humanos, julgamos ter um monopólio, e nas quais hasteamos nosso excessivo orgulho quanto à existência em nossa espécie: linguagem e consciência reflexiva" (MASSUMI, 2017, p. 10).

Com esta visão de que a experiência constitucional é algo inerente à vida como forma de protegê-la, o presente texto tem como objetivo refletir sobre o que enraíza a experiência constitucional ocidental como sua teoria explicativa, atualmente atravessada por demandas geradas pela crise da modernidade, que ampliou a ideia de sujeito de direito para todas as vidas e que demanda que o direito se vincule à sua pretensão de resolver conflitos com o fito de pacificar a sociedade. A questão é: como enfrentar à unicidade do projeto modernidade/colonialidade para expressar a pluralidade no constitucionalismo dos povos subalternizados? Tendo como resposta que o enfrentamento ocorre com a revelação do que foi ocultado e valorização do inferiorizado. A discussão foi feita sob a visão de que o método se realiza ontológica e epistemologicamente, e que a análise bibliográfica aqui realizada com levantamento em mapas de associação de ideias é orientação da modernidade como resistência. E como resultado do estudo foi produzida uma narrativa analítica sobre teorias explicativas do direito ocidental, resistências constitucionais da América Latina e de filosofias africanas, a partir de suas matrizes ontológicas como constitucionalismo e etnodireito. Para desenvolver o texto, o itinerário adotado foi: discussão do direito como constitucionalismo e vice-versa, o novo constitucionalismo latino-americano e as filosofias do bem viver e africanas, como etnodireito e pluralidades constitucionais. 


\section{Teoria do direito e teoria constitucional no paradigma modernidade}

Não há registro de sociedade sem um conjunto de regras que definam o dever ser e como lidar com os conflitos. É provável que Renan (1999), ao discorrer sobre nação em 1882 e afirmar não ser a nação definida por etnia, religião, língua ou interesses, estivesse se referindo ao que ele sabia sobre as nações que existiam e que foram desconsideradas pelo eurocentrismo. O fato é que as nações se organizavam por elementos concretos como etnia, religião, língua, interesses e territorialidade comum. $\mathrm{O}$ modelo ocidental artificializou os laços da comunidade política, com a declaração de vontade do povo, que forma a soberania sobre um determinado território, ou seja, a nação passa a ser formada exclusivamente pela vontade política de seus membros. E o modelo é definido nas primeiras nações a apresentarem suas constituições como Estado-nação, desconsiderando outras formas de pacificação social como as formas tradicionais de povos da Abya Yala, Pindorama e África, sendo estes últimos, nos dizeres de Serrano (2005), os que adotam a centralidade da palavra, como produção de consensos sobre os conflitos, em que se discute o conflito amplamente com toda a comunidade antes de julgá-lo. E a cerimônia termina com o compromisso de restaurar elos cindidos. As teorias explicativas do modelo constitucional se resumem a explicar o dever ser do Estado-nação sob a orientação de aplicar a pena ao caso, num paradigma retributivo, que resultou numa cultura punitivista de corpos eleitos para a punição, sem atender à sua funcionalidade que é a de pacificar os conflitos.

A teoria do direito retributivo é assunto recente! O direito sempre foi pensado por outras áreas do conhecimento, e o entendimento corriqueiro do direito é como técnica de resolução de conflitos afirmado pelo poder soberano. Quando Kelsen (1997) afirma uma teoria pura do direito cujo intento é refletir o direito por si mesmo e não pelas demais áreas do conhecimento. Kelsen toma como centralidade a afirmação de que o direito não se confunde com outros corpos normativos pelo tipo de sanção prescrita na norma, portanto, residindo a natureza jurídica do direito na sanção, sendo ela o fato de natureza social que vai compor suporte fático ou suporte condicional da aplicação que se faz pela subsunção: Se A é, B deve ser. A natureza jurídica é o B, o que deve ser, não por ser violência, mas por estabelecer a margem entre o direito e outros corpos normativos.

$\mathrm{Na}$ visão de Kelsen (2000), com base em Austin, o direito é comando que pressupõe dois elementos: o ato de vontade com a conduta do outro como objeto e sua expressão por meio de palavras, gestos ou sinais, sendo estes obrigatórios - portanto diferente do contrato -, mas exigindo concordância, o que permite afirmar a constituição como vontade política que valida o conjunto de normas prescritivas que compõem o direito em forma de normas gerais e abstratas e normas individuais - as decisões judiciais -, tendo como parâmetro de aferimento a validade e não a eficácia, que pode ser verificada nas esferas da pessoa, tempo, território e matéria, sempre aplicadas no presente e que só se 
referem ao passado como esquema de interpretação ou padrão de avaliação.

Kelsen (2000) afirma o direito como orientado pelo princípio da imputação e não da causalidade, o que difere o direito da natureza, aferida pelo princípio da causalidade. Quando alguém sofre uma sanção, a aplicação não é produzida no binômio causa e efeito, mas pela imputação de uma responsabilidade a alguém pelo seu ato ou omissão.

O autor referido apresenta sua teoria do direito como proposição, diferenciando-a da natureza prescritiva das normas, sendo a ciência jurídica atitude interpretativa dos fatos da conduta implicada na norma jurídica, tendo o seu labor na descrição de normas jurídicas, sejam as gerais e abstratas ou as decisões judiciais como juízos hipotéticos que enunciam ou traduzem o sentido de uma ordem jurídica, condições ou pressupostos fixados por esse ordenamento e consequências determinadas pelo mesmo ordenamento - o que diferencia a ciência jurídica do direito, sendo este imperativo normativo como prescrição, mandamento, comando, permissão, atribuição de poder, competência própria de autoridade.

Bobbio (1999) dialoga com Kelsen sobre sua teoria do direito afirmando ser a coerção o meio do direito e não fim, considerando o direito como ordenamento jurídico que tem sua validade na constituição, o que o faz afirmar as duas teorias, a da norma e a do ordenamento, como complementares, e que o problema do direito está localizado no ordenamento e não norma, já que é no ordenamento que se busca a validade das normas, que, para o aplicador, sempre será completo, coerente, coeso e uno, características garantidas pela Constituição.

Hart (1994) apresenta outra visão quanto à semântica do direito, afirmando ser o cumprimento das normas não corresponder ao temor da sanção, mas sua aceitação. Na reflexão quanto à persistência de aspectos da teoria do direito, o autor afirma ser o direito muito amplo para ser resumido ao padrão do direito criminal, considerando que as regras do direito proíbem ou impõem certos tipos de comportamento sob cominação de pena; exigem que as pessoas compensem aqueles que, por si, são ofendidos; definem o que deve ser feito para outorgar testamento, celebrar contrato ou outros instrumentos que confiram direitos e criem obrigações, além de fazer parte do direito o que fazem os tribunais para definir castigos ou compensação a serem pagas no seus atos de descobrir o direito pelas leis como fontes do direito e não como parte, fundado no poder do império do poder soberano não personificado, em que o soberano é também súdito.

O objeto de Hart não era tratar a técnica da subsunção, mas discutir os conceitos e trazer o dado de que o direito penal não é padrão, mas intervém na técnica ao afirmar que com as normas de textura aberta o juiz decide discricionariamente. Com a afirmação, o autor altera a técnica do direito e amplia os seus poderes, ao afirmar a liberdade de o juiz dizer sim ou não nos casos das normas principiológicas, assumindo assim os poderes do legislador e afirmando que nestes casos não há uma única resposta correta. 
A afirmação do Hart provocou a discussão de Dworkin (2003), que afirma a existência de única resposta correta para todos os casos do direito, cabendo ao juiz o esforço de a encontrar até mesmo nos casos difíceis. Para Dworkin (2003), o direito é ameaça e instrumento de defesa, por isso é espada, que tanto pode ser escudo quanto ameaça, que se faz por meio de opinião interpretativa como afirmações jurídicas que combinam passado e futuro no presente, resultando sua prática numa espécie de poder que pode levar à ruina ou à dignidade. $\mathrm{O}$ autor considera que o direito não é o conjunto de leis, pois os seus resultados figuram por meio das práticas dos juízes que apresentam quem tem razão por meio de prática argumentativa como exercício de interpretação.

O autor vê o direito como a melhor justificativa do conjunto de práticas jurídicas como narrativa que faz dessas práticas as melhores possíveis. As práticas jurídicas são interpretadas e discutidas pelas teorias do direito em forma de proposições jurídicas que buscam dizer o que o direito diz, havendo entre elas divergências quanto ao que é o direito e se o que diz o juiz é direito, como única reposta correta. O autor considera que as teorias que se limitam a definir o direito se portam como aguilhão semântico que busca eliminar a divergência entre as teorias de direito.

Para Dworkin (2003), o direito é exercício de interpretação em que o juiz descobre, inventa e cria o direito, mas como interpretação. A sua legitimação é para interpretar o direito e não para criar, havendo duas dimensões para interpretação: adequação, em que a interpretação possui poder explicativo geral e expressa o texto interpretado; e seleção, em que o intérprete seleciona de sua comunidade linguística os sentidos atribuídos ao texto interpretado no esforço de continuar a produção do direito como um romance em cadeia em que cada capítulo é formado pelas decisões judiciais produzidas, em que o intérprete não goza nem de liberdade nem de coerção plena, sob o risco permanente de ser considerada subjetiva ou objetiva sua decisão pelas opiniões de convencionais e pragmáticos.

A única resposta correta encontrada pelo juiz deve ter origem numa interpretação que, ao mesmo tempo, adapte-se aos fatos anteriores e os justifique, até onde isso seja possível, num delicado equilíbrio entre convicções políticas de tipos diversos. E nos casos difíceis, o juiz deve se aproximar muito de um tipo ideal, a que o autor chama de juiz Hércules, um juiz imaginário, de capacidade e paciência sobre-humanas, que aceita o direito como integridade e busca produzir decisões não como concepção geral, mas vinculadas ao caso concreto, à sua cor local, encontradas por meio mais de perguntas do que de resposta, mais das dúvidas do que das certezas, que buscam formar sua opinião como um romancista em cadeia a partir de alguma teoria coerente sobre os direitos legais, como juiz criterioso e metódico, que atua selecionando diversas hipóteses para corresponderem à melhor interpretação possível.

O juiz Hércules é o que atua com o direito como integridade e, por isso, toma o direito como estruturado por um conjunto coerente de princípios sobre justiça, equidade e devido processo legal adjetivo. E o seu exercício de interpretação tem por finalidade mostrar o que é 
interpretado em sua melhor luz possível. Uma interpretação de qualquer parte do direito deve, portanto, levar em consideração não somente a substância das decisões tomadas por autoridades anteriores, mas também o modo como essas decisões foram tomadas com o foco no caso concreto.

O juiz Hércules toma decisões com base em princípios, não em política e para isso apresenta argumentos que digam o porquê de as partes terem direitos e deveres, buscando produzir uma história da comunidade política melhor com a decisão que ele vai tomar, que é selecionada dessa comunidade como ato personificado na busca de produzir a melhor moral política substantiva possível.

O esforço de Dworkin (2003) é para salvar a cientificidade do direito como instrumento estatal de resolução de conflitos por meio do poder soberano, especialmente nos casos difíceis, indicando que até aí cabe ao juiz encontrar a única resposta correta.

Alexy (2011) considera que, naquilo que Dworkin chama de casos difíceis, há colisão de princípios que devem ser decididos pela ponderação ou sopesamento. O autor, na distinção que faz entre regras e princípios, afirma que os direitos fundamentais quase sempre são princípios, sendo mais gerais que as regras. E que no caso da aplicação de princípios, o critério é axiológico, ou seja, afirma algo assemelhado ao que defendeu Hart, com a diferença de que a decisão pelo poder discricionário deve tratar os princípios como mandamentos de otimização, como algo deve ser feito na melhor medida possível, considerando que estes podem ser satisfeitos em graus variados e que a satisfação depende de medidas fáticas e jurídicas, enquanto que as regras são normas que são satisfeitas ou não.

Para o autor, nos casos de colisão de princípios, o conflito se resolve pelo sopesamento, em que a decisão afirmará não colisão, mas tensão entre os princípios. O objetivo do sopesamento é definir qual dos interesses tem maior peso no caso concreto, em que a decisão não é resolvida com a declaração de invalidade de um dos princípios e com sua consequente eliminação do ordenamento jurídico, bem como não é resolvida por meio da introdução de uma exceção a um dos princípios para todos os casos futuros, mas consiste em estabelecer uma relação de precedência condicionada entre os princípios, com base nas circunstâncias do caso concreto. Para o autor, os princípios exigem que algo seja realizado na medida do possível dentro das possibilidades jurídicas e fáticas existentes e, por isso, não contém um mandamento definitivo, mas apenas prima facie.

O que Alexy (2011) apresenta é uma forma de resolver a técnica do direito fora do universo jurídico, com a avaliação de causa e efeito do que seja menos danoso para a sociedade a partir de orientações da ciência da administração, em que o administrador pode ir por qualquer um dos lados, os dois estão corretos, mas um deles produz melhores resultados, não havendo uma única resposta correta e com isso afirmando um poder criador do juiz para além da sua missão de aplicador da norma.

Luhmann (1983) busca a resposta para a complexidade do direito no âmbito do próprio direito por compreender que a sociedade se 
organiza como sistema social, portanto funcional, em ambiente complexo e contingente, visando manter relações entre as ações. E considera que o sistema emerge da diferenciação funcional no seu ambiente, que exclui o ser humano concreto como corpo social por ter sua dinâmica vinculada às funções - com separação entre direito e moral, entre verdade científica e direito e entre funções socializadoras, educadoras e edificadoras e o direito.

Luhmann (1983) revigora a técnica da aplicação do direito com a teoria sistêmica e reforça o positivismo jurídico ao afirmar como funciona a máquina do direito, a importância do seu código binário, a vinculação ao sim ou não que se dá pelo sistema e não pela decisão individual de cada aplicador. Considera que o direito não se origina da pena do legislador. Da decisão do legislador emerge uma multiplicidade de projeções normativas já existentes, entre as quais o juiz opta com um grau maior ou menor de liberdade, vinculado ao que diz a instituição em que atua, implicando que a decisão jurídica não reside na criação de direito, mas na seleção de normas e sentidos enquanto direito vinculativo.

Para o autor, o sistema adota um filtro processual pelo qual todas as ideias jurídicas tem que passar para se tornarem socialmente vinculativas enquanto direito numa dinâmica que gera sua estrutura em termos de inclusões ou exclusões que orienta o processo decisório em que a interpretação não se trata de algo criativo ou causal, visto que a mesma é produzida por estruturas sistêmicas que permitem o desenvolvimento de possibilidades e sua redução a uma decisão, produzida não pelo critério da fonte do direito, nem como ato individual, mas sim na experimentação seletiva constante e atual do direito. O direito vige enquanto direito positivo não apenas pela lembrança de um ato legislativo histórico, mas sua vigência se deve a uma decisão enquanto escolha entre outras possibilidades, sendo, portanto, revogável e modificável.

Luhmann (1983) considera que uma constituição não se fixa, em algumas de suas determinações, antecipadamente a uma forma determinada do direito, mas apenas regulamenta a forma de seleção do direito variável. Ou seja, o direito é uma norma isolada, mas a compreensão da função do sistema, a que atende, o que o fundamenta e como o poder será exercido, eis a constituição.

Habermas (1997) adota a perspectiva sistêmica e considera que o direito são duas coisas a um só tempo: um sistema de conhecimento e um sistema de ação, constando de um conjunto de textos que compreendam proposições normativas e interpretações, ao mesmo tempo em que é instituição que atua como reguladores de ação. Para Habermas (1997), o direito resulta de comunidade política de iguais pertencentes. Portanto, o seu ponto de partida são os direitos que os cidadãos devem concordar em reciprocamente se reconhecerem, e, ao ser positivado, não elimina a tensão permanente entre facticidade e validade, sendo o ponto de partida os direitos subjetivos, aqueles que definem as mesmas liberdades para todos os indivíduos ou sujeitos jurídicos, sendo a igualdade já declarada no próprio conceito de direito como leis 
universais e abstratas que autorizam que todos os sujeitos tenham acesso aos mesmos direitos.

O modo de produzir o direito é pelo deslocamento das expectativas normativas dos indivíduos moralmente desobrigados para leis que assegurem a compatibilidade das liberdades que se tornam legítimas por meio de procedimento legislativo que se funda no princípio da soberania popular, o que implica que a função do direito é estabilizar expectativas e que só pode ser cumprida se o direito preservar conexão interna com a força da ação comunicativa socialmente integradora.

Para Habermas (1997), direito e constituição se produzem em democracias, sendo a constituição a declaração de formação da comunidade política que tem como ponto de partida os direitos que os cidadãos se dão, os direitos fundamentais e a definição de como o poder será exercido na gestão da vida pública co-originária da vida privada.

O percurso da teoria do direito também como teoria da constituição apresentado na perspectiva do positivismo jurídico do ortodoxo ao contemporâneo denota um arranjo normativo para regular a vida de iguais pertencentes ao pacto de nação. Portanto, a sociedade que se estruturou negando a condição de iguais pertencentes por meio de filosofias, religião, moral, ética e teorias, não contou com os mesmos esforços para construir a ideia de nação de iguais pertencentes. Não é possível se verificar essa comunidade de interesses na formação da nação. Efetivamente, nenhuma sociedade vive isso! O modelo jurídico ocidental sofre de vários males. O mais significativo deles é a não inclusão com igual dignidade da maior parte da espécie humana, que foi a estratégia política para o modelo se afirmar como único e verdadeiro. A luta para se tornar igual pertencente aos pactos de nação vem gerando dinâmicas que alteram o modelo do direito e da constituição.

\section{Constitucionalismo e decolonialidade num mundo racializado}

O direito, que tem sua pretensa unidade na constituição, regula o Estado-nação em que vivemos, que se fez sob orientação ontológica e epistemológica da racionalidade moderna que se instaurou não na Europa, mas nos lugares colonizados na América como extensão da Europa em condição inferiorizada, na África como o outro também inferiorizado e, mais tarde, na Ásia com a colonização, que se mostrou como forma de exercício da arrogância da superioridade humana sobre outras vidas com fundamentos religiosos, classificando quem assim não pensasse como não humano. Portanto, o colonialismo é a expansão da subjetividade individualista que se fez voltada para um tempo inexistente, o futuro, como forma de alcançar o inalcançável.

Quijano (2005) indica o indício da colonização na passagem dos séculos XV para XVI, pela invasão dos europeus nos territórios de Abya Yala e Pindorama, que chamaram de América, e pela constituição de um espaço-tempo subalternizado, de modo a favorecer a colonização com a categoria raça, usada para naturalizar o processo - sendo, portanto, raça, a categoria mental da modernidade. 
Castro-Gómez (2005) considera que a invasão da América e sua conquista representava mais do que a criação de uma nova economia mundial: tratava-se, especialmente, da formação da primeira grande narrativa da modernidade e que tinha fundamentos religiosos. Numa leitura bíblica, via o mundo como o que restou do pós dilúvio dividido entre os filhos de Noé em três regiões: ao filho abençoado Jafé, coube a Europa; à Shem, que também foi castigado por não proteger Noé na sua fragilidade, coube a Ásia, o outro inferiorizado; e à Ham, o filho amaldiçoado, coube à África, que atuou como empírico de onde emergiu a ideia de organização racial do mundo numa hierarquia orientada pelo critério de diferenciação étnica, tendo a pele branca como superior e a não branca como inferior, sendo o violentado culpado pela violência que o ataca.

A racialização do mundo resultou em substrato material da formação do imaginário colonizado com a hierarquia de superioridade do colonizador e inferiorização do colonizado, incluindo aí a forma de ver o mundo, de categorizá-lo, nomeá-lo, as subjetividades e drasticamente as formas de conhecer, o que tornou eficaz o controle pelo pensamento como impeditivo para que o controlado se perceba como tal (FANON, 2008). E que a pessoa negra ou as não brancas, de modo mais amplo, sejam submetidas à inferiorização com regularidade e normalidade, de modo que passa a ser normal uma comunidade política declarar igualdade de pertencimento, como ocorre com o constitucionalismo ocidental, e as pessoas não brancas serem tratadas como não pertencentes à nação - seja nas políticas públicas, seja na aplicação das leis -, o que se tornou obstáculo à ideia de comunidade política formada por coassociados (HABERMAS, 1997) e faz do projeto de constitucionalismo uma quimera, caso não enfrente a estrutura racial que o conforma.

A modernidade não surgiu como projeto pronto nem no contexto da colonização, nem nas revoluções burguesas. Mas não se pode negar que a modernidade, desde as navegações, colocou-se como afirmação de comunidades políticas da Europa a partir de um pressuposto de não existência de outras comunidades políticas nos demais continentes, como estratégia de dominação em que a Europa é o espelho e o divergente não é civilizado, justificada a sua ação como uma pretensa benevolência de civilizar o planeta.

A modernidade é invenção religiosa do cristianismo afirmado como religião única, por isso monoteísta, que tem o sagrado como pai do universo e do ser humano, que é talhado à sua imagem e semelhança e serviu de fundamento básico para a superioridade humana a partir de uma subjetividade individualista que ganha o apoio da estética e das artes pelo romantismo que delineia a subjetividade vivida até os dias atuais, afirmando-se como única comunidade ou associação política a que chama de Estado-nação.

O sentido de comunidade política abstrata num modelo único com regras definidas acima da comunidade política para manter controle sobre o projeto é, de fato, invenção da Europa, que se fez negando a 
existência de política, direito, filosofia, ciência, economia, tecnologias, cultura de outras comunidades políticas que não a sua!

A narrativa da benevolência da civilização resultou na colonização contra os demais continentes, contra suas comunidades políticas, suas diferenças culturais e o seu pertencimento racial, em que só são tratadas como nação as comunidades políticas europeias. Portanto, o projeto constitucional europeu é erigido sobre os escombros de povos violentados, dizimados e comunidades políticas destruídas.

A estratégia adotada para colonizar rompeu com a ética de guerra que existia para uma comunidade política dominar outra, que implicava apresentar condições, exigências a um determinado grupo e, caso este não atendesse o solicitado, declarava-se a guerra e o resultado seria a submissão do perdedor e do seu território. Como afirma Segala (2016), ao estudar ética e guerra pelos referenciais gregos e romanos:

se o meio termo, a justa medida, é o dever final e o objetivo da sociedade ideal, esse meio termo é o que se deve buscar e aplicar nas guerras. A destruição nunca deve ser total, nem mesmo desmedida. Ela deve objetivar o fim dos confrontos e a solução eficiente para os problemas que imperam na relação entre os diferentes Estados. (...) Ainda que as leis mudem, a virtude deve manter-se soberana. E mesmo que a guerra torne-se assombrosa, o fim dela deve ser justamente equivalente a ambas as partes, sem ignorar as punições devidas aos que a causaram deliberadamente (SEGALA, 2016, p. 23).

Embora a citação refira-se aos gregos e romanos, é possível identificar uma ética de guerra nos poucos registros que há de povos invadidos pela colonização como refere Vidal (2001, p. 137), ao estudar o mito da guerra entre duas etnias brasileiras que guerrearam pelo direito de existir como se reconhece:

A guerra, no seu aspecto épico e heróico, é também uma performance com normas e comportamentos preestabelecidos". (...) Aqui, um fato histórico é assimilado às relações de afinidade. O conflito não se restringe a um confronto individualizado, mas toda a sociedade estará, automaticamente, envolvida. (...) Por outro lado, há um certo cuidado com as crianças que são "poupadas". Isto se verifica tanto no início como no fim do mito, quando após a batalha apenas sobrevive uma "txi colonie" (pequena colônia). Há também regras nessas guerras. Existem chefes militares que comandam um contingente de guerreiros. Pelo menos durante os primeiros embates, os chefes não podem ser mortos, porque caso o fossem a guerra acabaria. Tanto é assim que durante o primeiro combate, na Tipoca, do qual os Palikur saem vitoriosos, apenas o "sobrinho", chefe Galibi, se salva. Em outra batalha, às margens do rio 
Approuague, apenas o "tio", chefe Palikur, sobrevive (VIDAL, 2001, p. 137).

Ou seja, a afirmação é de que havia e há uma ética de guerra com valores e regras que definem um dever ser e a afirmação de que a colonização rompeu com a ética de guerra e implantou no seu lugar outro modelo de dominação, a colonização, que se tornou colonialidade nos tempos presentes e se traduz como ataque permanente para apagar a história do povo a ser dominado sob a alegação de que o domínio é para o bem do próprio povo. Com o apagamento da história, da cultura, da memória, do direito, da política, a inferiorização do povo sob uma regra de biologização da política iniciada pela inferiorização racial, que desresponsabiliza o dominador por seu domínio e transfere a carga da dominação para o suporte do inferiorizado.

O duplo biologização da política e o apagamento da cultura colonizada permanece como raiz de subalternização do presente, que teve início com a catequese, em que os conscientes da superioridade humana ensinam os considerados não conscientes desta superioridade, e, por isso, são tratados como não humanos. A técnica permanece nas escolas e universidades, em que as pessoas que chegam à escola e à universidade são tratadas como folha de papel sem nenhum registro, livres para que sejam impressos o que o comando eurocêntrico determina. Como uma das estratégias de afirmar o apagamento da cultura a ser dominada, surge a narrativa do constitucionalismo, que se fez hegemônica como o que só existe nos Estados-nação do modelo europeu e que o arranjo político constitucional teve início com as revoluções da modernidade, sendo considerada a primeira constituição, a dos Estados Unidos da América. Para Canotilho,

constitucionalismo é a teoria (ou ideologia) que ergue o princípio do governo limitado indispensável à garantia dos direitos em dimensão estruturante da organização político-social de uma comunidade. Neste sentido, o constitucionalismo moderno representará uma técnica específica de limitação do poder com fins garantísticos (CANOTILHO, 2012, p. 52).

Se tomamos constitucionalismo como a constituição de comunidade política de um povo que se autodeclara como tal sobre um determinado território, é impossível negar a existência de constitucionalismo ou de constituições onde há uma comunidade política. Portanto, os estados-nação que se afirmaram no seio do projeto de modernidade ocidental, fizeram-se negando e destruindo outras comunidades políticas existentes com práticas de sedução e assédio. E que a história do constitucionalismo ocidental, visto conforme Dworkin (2003), como a melhor narrativa que um povo faz de si ou a sua melhor estética que soa como poesia (HABERLE, 2004), foi e é produzida como violência e usurpação de um povo sobre outros. O que não impossibilita de, no presente, se construir constitucionalismo como uma comunidade de coassociados e assemelhados. Mas para atingir o feito há o legado da 
colonização e da escravidão atravessando o constitucionalismo de todas as nações. Um legado que sinteticamente se revela como colonialidade e racismo.

Quijano (2005) considera que a categoria raça foi criação dos colonizadores agregando os traços fenotípicos dos colonizados como raça inferiorizada, chamando a si mesmos de brancos e os colonizados de negros e índios, com a valorização dos traços brancos para cunhar de legitimidade a violência da colonização.

Com o tempo, os colonizadores codificaram como cor os traços fenotípicos dos colonizados e a assumiram como a característica emblemática da categoria racial. (...) Em consequência, os dominantes chamaram a si mesmos de brancos. (...) Na América, a ideia de raça foi uma maneira de outorgar legitimidade às relações de dominação impostas pela conquista. A posterior constituição da Europa como nova identidade depois da América e a expansão do colonialismo europeu ao resto do mundo conduziram à elaboração da perspectiva eurocêntrica do conhecimento e com ela à elaboração teórica da ideia de raça como naturalização dessas relações coloniais de dominação entre europeus e não-europeus. (...) os povos conquistados e dominados foram postos numa situação natural de inferioridade, e consequentemente também seus traços fenotípicos, bem como suas descobertas mentais e culturais. Desse modo, raça converteu-se no primeiro critério fundamental para a distribuição da população mundial nos níveis, lugares e papéis na estrutura de poder da nova sociedade. Em outras palavras, no modo básico de classificação social universal da população mundial (QUIJANO, 2005, p. 107-108).

Segundo o autor, raça foi inventada na colonização como legitimação e tornou-se critério fundamental e primário para classificação da população mundial e inferiorização do não branco. Segundo Mbembe (2014, p.10), o pensamento ocidental aborda "a identidade não em termos de pertença mútua (co-pertença) ao mesmo mundo", mas como espelho em que o pertencente ou o humano é sua própria imagem, tomando raça como sinônimo de negro, num projeto de conhecimento e de governo orientado por um viés evolucionista e linear como uma flecha do tempo com um antes, um durante e um depois como um infinito, recheados de promessas nunca cumpridas, por isso em forma de delírio.

Ainda segundo Mbembe (2014), no delírio da modernidade, o ser negro é o que ninguém quer ser, muito menos ser tratado como tal. Podemos afirmar que os povos originários como um todo se enquadram na qualificação do autor. E a diferença racial atua como uma espécie de fermento da dinâmica que torna o delírio cada vez mais delirante, cada vez mais fora do razoável. É o que faz parecer o projeto de constitucionalismo como comunidade de coassociados políticos um delírio ou impossibilidade nos contextos racializados e racistas. 
A modernidade é vista por Mbembe (2014) em três temporalidades: a da escravização; a das revoluções burguesas e dos escravos, aí situadas a Revolução do Haiti e a neoliberal da globalização, assentadas numa mesma lógica de senhor e escravo em que ser negro é ser escravo para ser abominado, degradado, desonrado (MBEMBE, 2014, p. 19).

Hegel (1992), em "Fenomenologia do Espírito", curiosamente escrita durante a Revolução do Haiti, identifica e analisa a lógica da modernidade na metáfora do senhor e do escravo como a dialética base da filosofia ocidental.

O senhor é a consciência para si essente, mas já não é apenas o conceito dessa consciência, senão uma consciência para si essente que é mediatizada consigo por meio de uma outra consciência, a saber, por meio de uma consciência a cuja essência pertence ser sintetizada com um ser independente, ou com a coisidade em geral. O senhor se relaciona com estes dois momentos: com uma coisa como tal, o objeto do desejo, e com a consciência para a qual a coisidade é o essencial. Portanto, o senhor: a) como conceito da consciência-de-si é relação imediata do ser-para-si; mas, b) ao mesmo tempo como mediação, ou como um ser-parasi que só é para si mediante um Outro, se relaciona a') imediatamente com os dois momentos; e b') mediatamente, com cada um por meio do outro. O senhor se relaciona mediatamente com o escravo por meio do ser independente, pois justamente ali o escravo está retido; essa é sua cadeia, da qual não podia abstrair-se na luta, e por isso se mostrou dependente, por ter sua independência na coisidade (HEGEL, 1992, p. 130).

O que Hegel apresenta é uma espécie de silogismo da dominação como estruturante do projeto ocidental: uma relação de dependência em que aparentemente o dominado depende do dominador, sendo aquele coisificado por este, que o retém. Os dois funcionam como uma unidade, um não existe sem o outro, ou melhor, o senhor não existe sem o escravo, mas no plano imediato é o oposto. E, para isso, os dois são desiguais e opostos, em que o senhor se relaciona com o escravo em dois momentos: a coisa, como o momento imediato, e a consciência, como o momento mediato.

Susan Buck-Morss (2011) estuda Hegel na obra referida e afirma que o autor compreendia a posição do senhor em termos políticos e econômicos, pois faz a leitura de que, no plano imediato, a aparência era que o escravo tinha necessidades físicas e o senhor não as tinha, mas que no plano mediato, ou seja, na verdade, a situação era inversa, em que o senhor é que era dependente e o escravo independente, mas este vivia para servir o outro e não era reconhecido como humano, sempre precisando do reconhecimento alheio, o que exige, na leitura hegeliana, que o escravo se conscientizasse e lutasse contra a sua coisificação para a situação se reverter.

Para a autora, Hegel fornece a lógica de funcionamento da modernidade na relação de dominação e exploração entre senhor e 
escravo. E relaciona a análise de Hegel com a revolução dos escravizados no Haiti, que fez parte do contexto em que Hegel produziu a referida análise, confirmando que a forma de exterminar a lógica que movia a escravidão era pela auto-organização movida pela autoconsciência para ser, de fato, a eliminação da lógica. A leitura que a autora faz da Revolução do Haiti é que a mesma se adequava ao que Hegel indicava como autolibertação, autoconquista pela autoconsciência, não significando a mera mudança de lugares entre o senhor e o escravo, considerando que, dessa forma, o instituto da escravidão não desapareceria, mas isso só ocorreria com a luta pelo fim da escravidão. Portanto, seria a síntese da dialética uma relação sem a escravidão.

Como se pode notar, embora o processo tenha vigorado, não significa que não houve resistência. Resistir à inferiorização da racialização, especialmente, pela escravização de africanos, segundo Clóvis Moura (1992), está junto da ação violenta de escravizar. Uma resistência que condiz com a metáfora do senhor e do escravo criada por Hegel (1992), exceto na responsabilização do escravizado pela própria escravidão.

Clóvis Moura nomina de quilombagem os processos de resistência à escravidão como "movimento de rebeldia permanente organizado e dirigido pelos próprios escravos, (...) uma força de desgaste significativa ao sistema escravista" (MOURA, 1992, p. 22), que atacava as estruturas escravistas no plano econômico, social e militar, e é a evidência de autoconsciência.

A resistência apresentada vai sendo construída no enfrentamento à estratégia colonial da inferiorização biológica e do apagamento cultural como revelação do ocultado, apagado, bem como revelação de sua natureza política, o que torna possível estabelecer relação entre a categoria quilombagem de Clóvis Moura com o pensamento e a epistemologia de fronteira do âmbito das discussões sobre decolonialidade, como afirmado por Mignolo (2000), enquanto resposta epistêmica da pessoa subalternizada vivendo os processos que a inferioriza e nele atuam na condição de subalterno. Portanto, não estando fora da relação modernidade/colonialidade, mas vivendo nas fronteiras, questionando as opressões, suas razões e estratégias e, dessa forma, construindo outro imaginário e memória pelo protagonismo como subalternizado que se interpõe contra a subalternização e, com isso, cria resistência para impedir o protagonismo, como ocorreu em muitos processos abolicionistas, que significaram, como afirma Susan BuckMorss, citando Hegel, "não uma libertação da escravidão, não por falta de luta, mas como estratégia para não exterminar a lógica da dominação" (p. 145), como manutenção do sistema de produção e reprodução do projeto ocidental.

As discussões que resistem ao par modernidade/colonialidade, que recebem denominações diversas - pós modernidade, descolonização, contracolonialidade, decolonialidade - também têm o objetivo de enfrentar o silenciamento sobre o tema da escravidão e suas sequelas no presente. Nelson Maldonado-Torres (2007) usou o termo giro decolonial 
para nominar os processos de resistência teórico-prática no âmbito do projeto modernidade/colonialidade.

Escobar (2003) afirma que a proposta decolonial adota uma perspectiva epistemológica de fronteira como resistência a partir do local da violência da colonialidade com sua versão de história única, linear e universal, organizada pela divisão do trabalho em binários, com início não nas revoluções burguesas como querem, mas na invasão da América, com o propósito planetário de classificação do mundo em que Europa é o centro e o topo, os demais são outros inferiorizados. E, para legitimá-lo, faz uso da racialização e, com esta, o controle do trabalho e da natureza. O autor afirma que do par modernidade/colonialidade apenas o primeiro termo aparece, sendo o segundo o que fica na penumbra, o lado semioculto da modernidade que tem como fim eliminar o outro, o local, o que for classificado como tradicional e atua como imaginário coletivo como poder e como intersubjetividade.

Quijano (1992) indica, como estratégia para enfrentar a colonialidade, a criação de uma epistemologia que possibilite enxergar o que estrategicamente é ocultado, que possibilite ver e significar o mundo e as experiências dos subalternizados pelo protagonismo, que altere a produção do conhecimento, que questione a ideia de totalidade do conhecimento e atenda ao propósito de reconstrução epistemológica para enfrentar a colonialidade.

Vale referir sobre os fundamentos da ideia de totalidade, de absoluto que alicerça a modernidade apresentada por Hegel (1992), como a base ontológica do pensamento hegemônico da modernidade que hierarquiza vidas, cria o falseamento da separação entre ser humano e natureza como separação de natureza e cultura, com base na ideia de que a espécie humana tem uma essência que o diferencia das demais, que é a capacidade racional, mas que a espécie só galga a condição de humanidade quando se conscientiza dessa capacidade em dois planos: consciência de si, o que se percebe como espécie diferenciada; e consciência para si, ou seja, o que intervém no planeta em benefício próprio por meio do trabalho para produzir riquezas.

O processo referido por Hegel (1992), o que leva o ser humano a desenvolver a consciência de si e para si, ocorre na medida em que o ser vai se autonomizando em relação às suas questões metafísicas com seu sagrado, que se torna ele próprio sem nenhum defeito, uma espécie de tipo ideal weberiano. Portanto, o espírito que é a essência do ser humano é sua racionalidade e o seu sagrado também é sua razão. O resultado da alquimia hegeliana é: o ser humano consciente de sua capacidade racional como única espécie do planeta, coloca-o em relação de superioridade na hierarquia da vida, com construção pela subjetividade; a ideia de que não são todos os humanos que chegaram à condição de consciência em si e consciência para si, havendo, portanto, seres da espécie que não alcançaram a condição de humanos, e que ter o sagrado na natureza ou nos animais é indicativo de não ter evoluído para a condição plena de humano.

A alquimia hegeliana - lamentavelmente não e só dele - é o alicerce de quem somos como racionalidade moderna ocidental: quanto mais 
ocidental mais humano, e ser mais ocidental é ser mais branco; é considerar lugar civilizado quando não há vidas classificadas como inferiores - as árvores, os rios, a terra e o ser humano não branco; é considerar que o sagrado fez o universo e colocou ao dispor do ser humano o poder para destruir todas as vidas sob seu controle para produzir riquezas; que só há um sagrado, aquele de quem o ser humano é a imagem e semelhança, que não interfere na vida cotidiana - cada ser humano dispõe de seu livre arbítrio e que é bondoso, que a tudo perdoa, bastando haver arrependimento, nem que haja reiterados recomeços; é ter sonho alimentado pela ideia de que o bom é o europeu, o direito, a ciência, a filosofia, a política, a economia, a tecnologia - se não for no modelo europeu não galga o lugar de legitimidade.

No enfrentamento da hegemonia referida, sempre houve resistências. Experimentando rever as nossas próprias experiências, é possível identificar como resistências ao projeto colonial a formação dos quilombos no passado e no presente; a resistência indígena, por ser resistência na vivência cotidiana. Vale referir ainda, no âmbito das resistências latino-americanas, as lutas por constituinte e as mudanças nas constituições em países como Brasil (1988), Colômbia (1991), Venezuela (1999), Equador (2008) e Bolívia (2009). Pela natureza da constituinte de cada um destes países, é possível afirmar que as últimas avançaram mais em mudanças normativas a partir do lugar negado na colonização.

Wolkmer (1989) define constituição como produto das dinâmicas sociais de um povo:

A constituição não deve ser tão somente uma matriz geradora de processos políticos, mas uma resultante de correlações de forças e de lutas sociais em um dado momento histórico do desenvolvimento da sociedade. Enquanto pacto político que expressa a pluralidade, ela materializa uma forma de poder que se legitima pela convivência e coexistência de concepções divergentes, diversas e participativas. Assim, toda sociedade política tem sua própria constituição, corporalizando suas tradições, costumes e práticas que ordenam a tramitação do poder. Ora, não é possível reduzir-se toda e qualquer constituição ao mero formalismo normativo ou ao reflexo hierárquico de um ordenamento jurídico estatal (WOLKMER, 1989, p. 14).

Dessa forma, o constitucionalismo latino-americano - ou novo constitucionalismo latino-americano - foi um espaço conquistado pelas lutas sociais e que o seu fazer não se concluiu ao serem proclamadas as novas constituições, mas a disputa permanece no âmbito da materialização do texto como políticas públicas e como aplicação em forma de decisões judiciais.

Fajardo (2010) considera a existência de três ciclos de novo constitucionalismo na América Latina, que tematizam a relação do Estado com povos originários: constitucionalismo multicultural (1982-1988), o 
constitucionalismo pluricultural (1989-2005) e o constitucionalismo plurinacional (2006-2009), sendo a marca do multicultural a inclusão do tema da diversidade cultural do país; como constitucionalismo pluricultural, a ratificação da diversidade cultural com a inclusão da perspectiva multiétnica e de Estado pluricultural, com catálogo de direitos indígenas, afro-americanos, dentre outros, com evidente vinculação à Convenção 169 da Organização Internacional do Trabalho (OIT); e como constitucionalismo plurinacional a perspectiva de refundação do Estado com reconhecimento explícito dos povos originários com adoção do princípio do bem-viver.

Considero que a divisão em três ciclos não deve ser vista como estanques, não dialogantes, por se tratarem tais constituições de processos de resistências que se comunicam. A Constituição do Brasil de 1988, por exemplo, estaria no primeiro ciclo, mas sabemos que os artigos 215 e 216 da referida constituição comportam chave hermenêutica de reconhecimento dos povos originários. E que a proteção aos modos de fazer e viver do art. 216 traz em si o princípio do bem viver.

Para Baldi (2018), os artigos 216 e 68 do ADCT da Constituição do Brasil não se encontram isolados em relação ao continente: pelo contrário, encontram-se inseridos numa dinâmica de grandes alterações dos sentidos de constitucionalismo com orientação para as concepções plurais de nação, cultura e etnias como dimensões de pluralismo jurídico ou ressignificação do constitucionalismo como resistência.

O processo de resistência para alcançar êxito há que ser vigoroso para enfrentar a um só tempo um poder que controla a economia, a autoridade, a natureza e os recursos naturais, o gênero e a sexualidade, a subjetividade e o conhecimento (MIGNOLO, 2010), figurando, portanto, numa tripla dimensão: a colonialidade do poder, do saber e do ser (MIGNOLO, 2003).

O que faz concluir que o constitucionalismo no âmbito de uma comunidade colonizada foi marcado por processos de resistência que atuaram contra a própria lógica do projeto ocidental. Porém, outras estratégias emergiram com o fim de enfraquecer a luta ou desfocá-la do seu propósito de enfrentamento à própria lógica que mantém o referido projeto colonialista.

Como já referido, Dworkin (2003) nomina constitucionalismo como a melhor narrativa que um povo faz de si e Haberle (2004) discute constitucionalismo e poesia numa referência ao constitucionalismo como a melhor estética de um povo, exemplificando com constituição que tem preâmbulo escrito por poeta, como o caso da Suíça. Assim sendo, afirmo que o racismo é a pior narrativa que um povo faz de si. E como fazer da péssima uma boa narrativa, ou mesmo a melhor? Penso que fazer dessa péssima uma boa narrativa não se faz apenas com alterações normativas. Como diz Fanon, é preciso modificar o imaginário que se tem sobre si e seus semelhantes, bem como as relações vividas para dar sentido diverso ao que é ser semelhante. 


\section{Juridicidade restaurativa e etnodireito na ontologia do bem viver}

A racionalidade moderna se construiu sob a falsa propaganda de que se o tráfico era cruel, pior seria viver na África selvagem. James (2010), em sua densa narrativa sobre a Revolução do Haiti, silenciada para não inspirar outras revoluções, afirma que:

A propaganda da época alegava que, por mais cruel que fosse o tráfico, os escravos africanos eram mais felizes na América do que na sua própria civilização africana. (...). No século XVI, a África Central era um território de paz e as suas civilizações eram felizes. Os comerciantes viajavam milhares de quilômetros de um lado ao outro do continente sem serem molestados. As guerras tribais, das quais os piratas europeus afirmavam libertar as pessoas, eram meros simulacros; (...). Foi sobre um campesinato, em muitos aspectos superior ao dos servos em amplas áreas da Europa, que o comércio de escravos recaiu. (...) As tribos tinham de suprir o comércio de escravos, ou então elas mesmas seriam vendidas como escravas. A violência e a ferocidade tornaram-se necessidades para a sobrevivência (...). Os crânios sorridentes na ponta de estacas, os sacrifícios humanos, a venda dos próprios filhos como escravos: esses horrores foram o produto de uma intolerável pressão sobre os povos africanos, que se tornavam mais ferozes, no decorrer dos séculos, à medida que a exigência da indústria aumentava e os métodos de coerção eram aperfeiçoados (JAMES, 2010, p. 21 e 22).

O autor continua a descrição da engenharia da escravidão com o relato de como as pessoas capturadas para a escravidão eram transportadas até o navio, com "pedras de 20 a 25 quilos para evitar as tentativas de fugas" (JAMES, 2010, p. 22) ao demonstrar a transformação de seres humanos em coisa sob as bênçãos da religião católica e sob o silêncio dos teóricos que construíam as bases filosóficas iluministas.

O autor citado acima apresenta como os que não se conformaram com o tratamento recebido, fizeram a revolução do Haiti no final do século XVIII e início do século XIX, com destaque para Toussaint L'Ouverture, tratando-os como jacobinos negros, porque, curiosamente, as revoluções burguesas ocorriam sob a arquitetura da escravidão e da Revolução do Haiti. O que o autor apresenta faz ver a relação violenta e assimétrica produzida pela colonização no conjunto do colonialismo.

Como produzir relação horizontal de igual pertencimento à comunidade política como referido pelo constitucionalismo sobre os escombros racializados com a escravidão atualizada pelo racismo? Como instaurar elos no lugar da dor oriunda da colonização que permaneceu como colonialidade? Isso demanda repensar os territórios subalternizados.

Vale considerar a indicação feita por Latouche (2010 e 2013), que para pensar a África como outra implica considerá-la pelo que a mesma 
tem e não pelo que falta para ser igual à Europa, o que exige a descentralização cognitiva para perceber um outro com suas estratégias de auto-organização, como a economia do "débrouille" (LATOUCHE, 2013, p. 176), que, no lugar da mão invisível do mercado, há relações sociais e econômicas com mãos visíveis e reais orientadas pela lógica da reciprocidade.

A visibilidade que o autor procura dar às relações econômicas que são vistas como informais, alternativas, chama atenção não pelo que significam no plano imediato tais relações econômicas, mas pelo que as estruturam: o espírito de dom e as lógicas de reciprocidade, que foram funcionalizadas e artificializadas na racionalidade moderna (DURKHEIM, 1987), sob a justificativa de pressupostos de sua existência concreta. $E$ isso atua como memória da função, ou seja, a solidariedade orgânica, a artificializada é negativa, com a pressuposição de existência da solidariedade real, a que o autor chama de positiva.

Latouche (2013), ao se referir sobre o sentimento de solidariedade de povos africanos, cita o caráter animista das sociedades que foram tomadas como não civilizadas, como crenças irracionais, portanto, desnecessárias, mas que tinham importante papel na defesa da natureza e no controle da ação humana na relação do que é chamado de meio ambiente.

Se a píton é meu ancestral, como pensam os Ashanti, ou o crocodilo, para os Bakongo, é difícil fabricar cintos e bolsas com seu couro. Se as florestas são sagradas, como podem ser exploradas racionalmente? Na África, até hoje, enfrenta-se este tipo de obstáculo ao desenvolvimento. No sul do Togo a exploração da lagoa de Anecho, morada do crocodilo totêmico, só foi possível depois da expulsão de uma parte dos moradores. O mesmo ocorreu com a lagoa Ebrié em Abidjan, que foi palco de graves conflitos com a população local (LATOUCHE, 2013, P. 181).

Há acima a evidência de estratégias de proteção ambiental que resistiram ao projeto ocidental, que Latouche (2013, p. 187) chama, "sociedade vernacular [que] se inscreve na persistência, ou até mesmo na ressurgência de uma certa 'solidariedade africana'". E no âmbito desse tipo de solidariedade, a funcionalidade aparece num segundo plano e não como a principal. É como se fosse a inversão da lógica ocidental: em que a solidariedade funcional é que é pressuposta. Daí a valorização da consciência coletiva ou comum, a importância das relações de parentesco, o parentesco extenso que se chega às relações de amizade, de vizinhança, política, religiosa, as relações de trabalho e às formas de poder, o que é reforçado pelas cerimônias, cultos aos ancestrais, ligações com a terra e com o mundo invisível. Esse tipo de solidariedade, considerada pelo autor como polimórfica, permanece até quando ocorre a migração.

Latouche (2013) afirma que o tipo de solidariedade referida opõese ao isolamento e a solidão ocidental, manifesta-se como solidariedade nas dificuldades, que se materializa em ações de doação e de retribuição, 
que tecem os laços entre as pessoas, entre humanos e o sagrado, vivos e mortos, pais e filhos, entre os mais velhos e os mais novos, entre homens e mulheres e entre gerações e na relação destes com a natureza.

A solidariedade referida é identificada na resolução de conflitos nas referidas comunidades por meio da dinâmica da reunião ou "palabre", que vem sendo associada ao fenômeno das consultas nacionais, locais como modelos de resolução de conflitos pela recomposição, nas quais as sociedades civis afirmam a exigência democrática e a desaprovação de ditaduras corruptas, mas é possível ver além disso, como uma juridicidade restaurativa pela lógica da reciprocidade, diversa da forma ocidental conflitiva:

De forma que a democracia pode ser vista como fundada no modelo referido, em que por meio de reuniões comunitárias se atinge o fim de pacificar o grupo social: a "palabre" é uma espécie de consulta "onde os anciãos se reúnem embaixo da grande árvore e discutem até chegarem a um acordo", sendo portanto a "palabre" (...) modo de gestão de conflitos", como forma de resolver muitos problemas internos e externos, considerando também que "a palabre" pode evitar justiça com as próprias mãos, "formas de justiça imediata e expeditiva com linchamento público ou a agressão" (LATOUCHE, 2013, 189 a 191).

A citação refere ao comunitarismo vivido nestas sociedades, em que o direito tem a finalidade de pacificar os conflitos vividos, com exercício de poder dos mais velhos por serem as pessoas mestras na arte da palavra e no conhecimento dos costumes, que atuam como guardiães da memória da sociedade, reconhecidos como griôs, e que a palavra, que pode ser entendida como consenso, atua para evitar o risco de autoritarismo pelos anciãos, sem deixar de usufruir das suas experiências que conhecem a história, os meios de garantir a subsistência e sabem enfrentar os problemas de administração das relações humanas, tais como luto, divórcio, conflitos, e "interagir com as autoridades ancestrais (que têm o controle da chuva, da fertilidade e da fecundidade)" (LATOUCHE, 2013, p. 192).

O autor relaciona a palavra com a razão prática como ação social efetiva, não apenas como instituição jurídica, embora muitas vezes possa se assemelhar com um tribunal, mas não se limita ao jurídico, sendo também político. Portanto, junta o que a racionalidade moderna separou que não se separa efetivamente, direito e política, que pressupõem igualdade e liberdade de expressão. Por isso recoloca e valoriza o papel do simbólico.

O que autor indica é uma espécie de configuração do jurídico/político como oposto à lógica ocidental. Primeiro, por associar o que o ocidentalismo pretendeu separar, a relação direito e política. E por alargar a cena jurídica incluindo a restauração de elos sociais cindidos no conflito como fechamento da relação jurídica. Enquanto no direito positivo ocidental o jurídico é concluído na decisão judicial e, portanto, 
se fecha na sanção, já a palavra inclui o momento pós, o da produção da conciliação como restauração vinculada ao contexto, à singularidade do caso e aos sentimentos produzidos no contexto.

Serrano (2005), ao analisar como povos tradicionais africanos resolvem conflitos, considera que, para resolver conflitos, estas sociedades enfrentam o conflito pelo debate com todos os membros da comunidade visando restaurar os elos cindidos.

O autor considera que, para estas sociedades, a palavra falada, além do seu valor moral fundamental, tira do sagrado o seu poder operativo e encontra-se em relação direta tanto com a manutenção como com a ruptura da harmonia, seja do ser humano, seja do mundo que o cerca, sendo a palavra essencial na socialização das pessoas como expressão do poder e da ordem, não só da ordem cósmica, mas da ordem social, sendo sua eficácia atribuída na crença coletiva do poder da força vital contida na palavra, no rito que a desencadeia, bem como nos seus suportes biológicos, na figura do ser humano, ou nos seus suportes materializados como objetos utilizados nos rituais criados pelas pessoas.

Serrano (2005) afirma que, para estes povos, a troca de palavras é momento próprio de comunicação entre as pessoas, com a necessidade de a palavra ser correta e apropriada, vinculada com a ancestralidade e como elemento essencial para busca de consensos, em que a socialização é a troca direta da palavra que permite a transferência das experiências no seio do grupo, e, deste modo, na reprodução da vida social, figurando a troca de palavras não como mera troca linguística interindividual, mas como fato comunitário que atravessa todas as dimensões da comunidade.

Sendo a palavra comunitária a forma tradicional que um grupo transmite todos os seus valores e as experiências vividas como processo educativo para as novas gerações, isso faz com que a palavra assuma sentidos centrais na vida política da comunidade como reunião, espaço de discussão, assembleia, lugar de expressar as palavras públicas e com o sentido explícito de resolver conflitos.

Nos julgamentos de conflitos, o conjunto da comunidade é chamado a participar, e não só enquanto observador, atuando como as partes, com discussão prolongada que pode durar vários dias e a busca de um consenso pelas várias partes torna-se mais importante que a punição em si. Sempre que é referida, a palavra ancestral evita a dissensão e recria a unidade participativa desejada pela sociedade (SERRANO, 2005).

No espaço da palavra, um discurso pode relatar acontecimentos reais ou fictícios como forma de encadear os acontecimentos e transformar os fatos em histórias inteligíveis, em que o lugar que seria o tribunal atua como espaço cênico onde ocorre a constituição ou reconstituição dos fatos numa narrativa em várias vozes, feita de versões sucessivas, com as partes contrárias por si próprias, por defensores de suas narrativas ou por especialistas. Dessa forma, os conflitos são resolvidos em processos como ritos de passagem com quatro etapas: tentativa de conciliação; instalação do espaço público como rito de separação, em que as narrativas são contadas e defendidas; o julgamento, em que os conflitos tem solução com a garantia de igualdade entre as 
pessoas no espaço público; e o rito de agregação, onde finalmente se consegue a volta à normalidade, à harmonia, onde mesmo quando aquele que é penalizado é incorporado no seu grupo (SERRANO, 2005).

Como se pode notar, o objetivo da palavra é mais a pacificação e a reconciliação e menos a busca da justiça abstrata em si, incluindo soluções místicas nas quais podem ocorrer de nenhuma pessoa ser denunciada e o conflito ser atribuído a um mau espírito, embora se saiba quem fez. Mas perdoar para reconciliar e reestabelecer os laços históricos pode exigir a solução sobrenatural sempre com a aprovação do público, em que, "a unanimidade dava a todos o sentimento de viver em comunidade junto com os espíritos dos ancestrais". Entre os Odjukru da Costa do Marfim, a palavra termina com cerimônia, na qual cada pessoa prova o sal para esvaziar o rancor guardado (LATOUCHE, 2013, p. 194).

A função do sobrenatural, que é acionado como sagrado, é sancionar e garantir a decisão jurídica, concluindo a palavra com a reconciliação, que pode, inclusive, conter contradições, mas, desde que reconcilie, a reunião atinge o seu fim. E mesmo os mais velhos precisam convencer, persuadir, num igualitarismo que não se confunde com a igualdade abstrata do modelo ocidental.

O paradigma ocidental também é questionado por povos originários das Américas. Huanacuni (2010) indica que, para discutir a crise do modelo ocidental, há a concepção cosmogônica comunitária, dando como exemplo as nações nativas de Abya Yala, que, mesmo com diferentes expressões culturais, adotam o paradigma de vida comunitária, não se limitando à relação social, mas de profunda relação com a vida. $O$ autor cita a nação Aimara e a nação Quechua, que entendem que tudo tem duas fontes: Pachakama ou Pachatata (Pai cosmo, energia ou força cósmica) e Pachamama (Mãe terra, energia ou força telúrica), que geram todas as formas de existência.

O autor afirma a concepção cosmogônica dos povos originários das américas como busca permanente do equilíbrio numa visão multidimensional, que inclui espírito, natureza com todas as vidas, sendo a terra o ponto de encontro de todas as vidas, em que o indivíduo não desparece na comunidade, mas emerge, numa complexidade que eestá além do código binário ocidental do sim e do não.

As discussões feitas têm o objetivo de ver outras ontologias e epistemologias balizadoras das formas de lidar com as regras para que vejamos a falibilidade do projeto jurídico e político da modernidade, além das experiências sobreviventes ao modus operandi ocidental, e com elas aprender.

A base referida me permite arguir a demanda por uma concepção de um direito pelo pertencimento cultural à comunidade política, o que me leva a referir à categoria etnodireito, considerando que diferentes culturas significam formas diversas para lidar com os conflitos, produzir consensos, definir e controlar as relações de poder, as relações sociais da produção e divisão de bens e riquezas.

Barth (1995) trata etnia como forma de organização social das diferenças culturais considerando-a como instável e imprecisa na sua definição de conteúdo e limites. Portanto, estando marcada pela 
mobilidade, que resulta numa perspectiva de etnicidade maleável, negociada, sendo etnia equiparada a pertencimentos raciais, territoriais, religiosos, linguísticos, com relações e intercâmbios com outros grupos, com a sociedade e com o Estado.

Segundo Abner Cohen (1974 apud ARRUTI, 1997), a etnicidade é forma de interação de grupos culturais que agem num contexto comum ou num espaço conectado. Ainda com Barth (1995), a etnicidade é definida nas fronteiras entre um grupo e outro, pelo contato entre diferentes grupos, o que faz definir a etnicidade pelas diferenças entre os citados grupos, estando, portanto, relacionada com identidades de um povo.

Para Canclini (2006), a identidade étnica de um grupo é formada pela comunicação entre os diferentes grupos, inclusive com absorção de traços culturais diferenciados, em estado permanente de construção. Hall (2004) considera como fator importante na construção e reconstrução identitária o sentimento de pertencimento a uma determinada cultura, o que faz com que as pessoas busquem traços para se identificar.

Rosenfeld (2003), ao estudar a identidade do sujeito constitucional como diferente das identidades socioculturais, tomando estas como préconstitucionais, refere-se ao constitucionalismo como sentimento. E usa uma analogia de metáfora e metonímia para qualificar a identidade do sujeito constitucional: metáfora em razão de todos os sujeitos constitucionais comportarem na referida identidade e metonímia porque todos são parte da unidade constitucional, sendo o mesmo a um só tempo autores da constituição e estando a ela submetidos. E só por ser autor é que é submetido, como submetido a si próprio, atuando na cena constitucional pelo sentimento de pertencer à comunidade política definida pela constituição.

As duas naturezas identitárias, a pré-constitucional e a constitucional, e o sentimento em ambas de pertencimento, fazem-me acionar o direito democrático como etnodireito, ou seja, o direito como igual pertencimento à comunidade política constitucional, sendo o mencionado sentimento o que alimenta a luta permanente da comunidade política pela garantia da condição de pertencente.

Vale lembrar que o pano de fundo e o horizonte do projeto de nação e de vida é a dimensão ontológica como sentido do ser, sua natureza e existência que nos guia com a flecha apontada para o ideal de vida boa que queremos, lembrando que a ontologia da lógica ocidental é orientada para o futuro. E para alcançá-lo, o itinerário é feito como evolução ou desenvolvimento. A referida ontologia não define todos os povos. A herança de povos originários traduz o seu ser como o que busca o bem viver, como consta em constituições como a da Bolívia e do Equador.

$\mathrm{Na}$ perspectiva aristotélica, a evolução tende a conduzir tudo para um bem, que se encontra na ideia de felicidade, a que o ser humano alcança cultivando as virtudes por meio de ações nobres e de boas escolhas, de modo que a felicidade emerge como manifestação ética a partir do conhecimento: 
Se, pois, para as coisas que fazemos existe um fim que desejamos por ele mesmo e tudo o mais é desejado no interesse desse fim; e se é verdade que nem toda coisa desejamos com vistas em outra (porque, então, o processo se repetiria ao infinito, e inútil e vão seria o nosso desejar), evidentemente tal fim será o bem, ou antes, o sumo bem (ARISTÓTELES, 1991, p. 2).

O bem a que se busca que tem na ponta da flecha a vida boa virtuosa aristotélica estabeleceu a lógica sobre a qual foi desenvolvido o projeto ocidental, sendo o seu ser o que evolui para um pretenso bem e, portanto, aquele que busca desenvolver-se. Daí a colonização justificada como ação que, apesar dos meios violentos, destinava-se ao bem em forma de civilização que, na verdade, tratava-se de usurpar territórios e suas riquezas sob a dominação racializada dos povos não brancos. E as estratégias para o projeto ganhar as vestes de bem incluíam atestar que os povos colonizados não eram civilizados, senão selvagens, o que implicou negar o pertencimento dos povos a culturas existentes, com o branqueamento destas culturas - como o caso do Egito -, ou simplesmente ignorando-as e omitindo qualquer explicação sobre as culturas dos povos originários das américas:

Se existissem 'provas' científicas de que os negros são biologicamente inferiores, como poderíamos explicar que o Egito antigo-inconvenientemente localizado no continente africano? Havia duas, ou melhor, três soluções. A primeira era negar que os antigos egípcios eram negros; a segunda era negar que os antigos egípcios haviam criado uma civilização; a terceira era negar ambas as hipóteses. Foi essa a alternativa favorita da maioria dos historiadores dos séculos XIX e XX (Bernal apud SHOHAT, 2006, p. 92).

A colonização racializou o mundo e criou falsas unidades da Europa, da África e das Américas submetidas ao racismo numa invenção de tradições para justificar a hierarquia racial e cultural: "a própria invenção da África (como algo mais do que uma entidade geográfica) deve ser entendida, em última instância, como um subproduto do racialismo europeu" (APPIAH, 1997, p. 96), com suas fronteiras arbitrárias, bem como a invenção da Europa pelo discurso de vencedor que equipara:

a história ao avanço da razão ocidental, a própria Europa é na verdade uma síntese de diversas culturas, ocidentais e não-ocidentais. A noção de uma Europa 'pura' nascida da Grécia clássica se apoia em claras exclusões, que vão desde as influências africanas e semíticas sobre a própria Grécia clássica até as osmoses das culturas islâmicas e judaicas (SHOHAT, 2006, p.38).

Não desconsidero o risco de enfrentar a unidade criada pelo eurocentrismo com outra unidade de pan-africanismo, que seria enfrentar 
uma invenção com outra sem substrato de evidência na realidade, uma mentira com outra mentira. Embora seja razoável um movimento político pan-africanista como unidade de resistência para enfrentar a unidade racializada criada pelo eurocentrismo.

Segundo Hernandez (2008, p.138), o pan-africanismo foi uma espécie de movimento "político ideológico centrado na noção de raça, noção que se torna primordial para unir aqueles que, a despeito de suas especificidades históricas, são assemelhados por sua origem humana e negra", sendo raça o conceito aglutinador com o objetivo de criar um ethos comum que incorporasse todas as pessoas africanas.

Embora seja importante a movimentação nominada de panafricanismo no sentido de aglutinar as culturas e povos que sofreram e sofrem os desatinos da colonização, uma reflexão que seja capaz de questionar a unidade eurocêntrica precisa ser capaz de ler a pluralidade desses povos e culturas.

A perspectiva ontológica para questionar o ethos orientador da unidade eurocêntrica precisa expressar diversidade e não unidade, pela própria lógica hegeliana, considerando que a modernidade/colonialidade se fez como como unidade a partir de conceitos tratados como universais. Portanto, o deslocamento da referida ontologia há que ser antitético para efetivamente chamar atenção para o lado não visível, a colonialidade que domina, controla, explora, subalterniza, e que é mantida pela retórica da modernidade com sua pretensão de universalidade (MICNOLO, 2008).

A resistência precisa adotar a perspectiva ontológica e epistêmica da diversidade para ler o que foi afirmado como universalidade. A perspectiva do novo constitucionalismo latino-americano, segundo Médice (2010), com base em processos constituintes da Bolívia (20062009) e do Equador (2007-2008), que se deram por meio de mobilização social, especialmente, das populações que se organizam como guardiãs dos povos originários das Américas, questiona e problematiza a unidade da modernidade/colonialidade, especialmente ao adotar a unidade do Estado-nação como plurinacional.

Médice (2010) considera que os referidos processos constituintes resultaram em uma horizontalidade na constituição com 0 reconhecimento e proteção à diversidade de saberes e práticas de uma pluralidade de culturas e de ontologias e epistemologias que foram historicamente silenciadas; se há uma unidade, esta reside em reconhecer a pluralidade, e que a essência do ser é o bem viver a partir da perspectiva de cada povo e de cada diversidade cultural na sua relação com a natureza e com todos os seres, como resistência à hegemonia ocidental, que as atravessa permanentemente.

A concepção de bem viver como ontologia que questiona e enfrenta a ontologia da modernidade/colonialidade foi referida na Conferência Mundial dos Povos sobre Mudanças Climáticas e os Direitos da Mãe Terra, em Cochabamba, Bolívia, em abril de 2010, que aprovou a Declaração Universal dos Direitos da Mãe Terra, cujo artigo $2^{\circ}$ reconhece o planeta terra como sujeito de direito com a seguinte definição: 
A Mãe Terra é um ser vivo, uma única comunidade, indivisível e auto-regulada, de seres interrelacionados que sustem, contem e reproduz a todos os seres que a compõe, que cada ser se define pelas suas relações como parte da integrante da Mãe Terra.

Para Gudynas y Acosta (2011), a ontologia que embasa a concepção da terra como sujeito de direito é a do bem-viver como forma de pensar em construção no quadro de disputa pela ressignificação da constituição no âmbito da América Latina, que está problematizando o ser do projeto moderno do ocidente, voltado para uma perspectiva de sociedade em que convivem os humanos entre si e com a natureza, fundada na crença da necessidade de revisão da relação entre humanos e as forças cósmicas e telúricas, relativas ao sol e à terra como Pachamama, tendo como valor a harmonia na relação entre os seres orientada pela inclusão, solidariedade, reciprocidade, respeito, complementaridade e equilíbrio como resistência a hierarquia de vida da cultura ocidental.

Gudynas (2011) considera que o bem viver é uma forma perceber e conceber a vida e o mundo a partir da relação humano e natureza que assegure simultaneamente $\mathrm{o}$ bem estar das pessoas e a existência concomitante das espécies, de plantas, animais e dos ecossistemas, que demanda outra consciência a partir de outra forma de conhecer, compreender a vida e se conduzir no mundo, especialmente, que substitua as estruturas de pensamento ocidental pela ontologia do bem viver, tendo a vida como valor ao invés da economia ou mercado.

A ontologia se faz pelo conhecimento, com combinação epistemológica como enraizamento da concepção de vida por ser o meio de intervir no pensamento e alterá-lo. René Descartes (2001) ao refletir como atuar no mundo depois de ficar privado de locomover-se em razão dos maus tempos, inaugura outra forma de conhecer, a forma compartimentada rompendo com a relacional. Embora Latour (1994) afirme que jamais fomos modernos, entendo que a crítica do autor se dá no sentido de que nunca conseguimos deixar de viver de modo relacionado. Ou com os híbridos e em rede como afirma o autor. Mas sabemos que a modernidade existiu e existe como episteme que divide, classifica, categoriza pela atribuição de valor e com isso hierarquiza.

O principal desafio da igualdade constitucional é enfrentar as hierarquias criadas pela modernidade/colonialidade vistas como monismo jurídico de modo relacional, plural, diverso (WOLKMER, 1989). E que nesta diversidade há um processo estruturante de inferiorização que é preciso ser identificado em suas várias facetas e simbologias e adotar políticas para enfrentá-lo. O intérprete da igualdade constitucional precisa saber como foi estruturada a história daquela nação para compreender o que ronda a igualdade constitucional e o que a coloca em perigo ou mesmo torna-a impossível.

Aqui o giro também precisa ser decolonial, ou seja, a partir do lugar da negação da dignidade da outra pessoa. Ao lado da norma da igualdade há que haver a norma que reconhece a existência da desigualdade estruturante e que a enfrenta como oportunidade de construir um 
constitucionalismo como a melhor estética e a melhor narrativa que fizermos de nós, que permita ver nas pessoas negras e povos originários das américas um sujeito que é reconhecido e se autorreconhece como sujeito constitucional e que atua com seus pares para enfrentar os percalços da vida cotidiana.

\section{Considerações finais}

O texto discorreu sobre monismo estatal e a oportunidade dele ser lido como pluralidade pela revisitação a experiências subalternanizadas africanas e latino-americanas. A discursividade foi feita com narrativa sobre o par modernidade/colonialidade, sendo a segunda parte a que alcança visibilidade, como a que vai tornar possível a modernidade por meio da inferiorização do outro, para colocá-lo sempre na condição de subalterno, e que atua como estrutura de pensamento como afirma Fanon.

A lógica desse poder que se hegemonizou é indicada por Hegel na metáfora do senhor e do escravo, que funciona como unidade e que vencer a lógica ocorre mediante auto resistência, que, na visão de Clóvis Moura, sempre houve, sendo o diferencial no giro decolonial a consciência que se tem sobre o poder do projeto e a certeza de que o mesmo só será enfrentado no seu próprio ser, isto é, ontológica e epistemologicamente.

O texto dá destaque para duas experiências de resistência: as práticas de resolução de conflitos em povos tradicionais africanos, apresentando uma juridicidade com foco na pacificação das relações em conflito e a experiência constitucional latino-americana como pensamentos de fronteira que questionam o ser da modernidade/colonialidade nas dimensões ontológica e epistêmica, que ganham a forma de etnodireito com a perspectiva de que é possível, até mesmo na unidade do direito, ser produzida pela comunidade política constitucional a sua tradução como diversidade de acordo com seus próprios fundamentos com enfrentamento às hierarquias produzidas pelo modelo natural e com a negação e ocultamento da cultura que inferioriza.

As experiências de resistência estão apropriadas para pensar a própria crise da juridicidade moderna em razão de esta ter se formado pela amputação da centralidade do direito, que é pacificar as relações em conflito. O alargamento da juridicidade para que o direito alcance o seu fim, que é a restauração dos elos cindidos nos conflitos, e a experiência do constitucionalismo latino-americano com sua visão cosmogônica da vida são boas oportunidades para refletirmos sobre a crise da juridicidade ocidental. 
Espaço Ameríndio

\section{Referências bibliográficas}

ALEXY, Robert. Teoria dos direitos fundamentais. São Paulo : Malheiros, 2011.

APPIAH, Kwame Anthony. Na casa de meu pai: a África na filosofia da cultura. Tradução Vera Ribeiro. Revisão de tradução Fernando Rosa Ribeiro. $1^{\mathrm{a}}$ edição; $1^{\mathrm{a}}$ reimpressão. Rio de Janeiro: Contraponto, 1997

ARISTÓTELES. Ética a Nicômaco. Tradução de Leonel Vallandro e Gerd Bornheim da versão inglesa de W. D. Ross. 4. ed. (Os pensadores ; v. 2). São Paulo : Nova Cultural, 1991.

ARRUTI, José Maurício. A emergência dos "remanescentes": notas para o diálogo entre indígenas e quilombolas. Revista Mana vol.3 n.2 Rio de Janeiro Oct, 1997.

BALDI, César Augusto. Novo Constitucionalismo Latino-Americano. In: Jornal Estado de Direito. 32 ed. Disponível em: $<$ http://www.estadodedireito.com.br/2011/11/08/novoconstitucionalismo-latinoamericano/> . Acessado em: 16 de abril de 2018 .

BARTH, Fredrik. Etnicidade e o conceito de cultura. Tradução: Antropolítica: Revista Contemporânea de Antropologia e Ciência Política n. 1 (2. sem. 95). Niterói : EdUFF, 1995.

BOBBIO, Norberto. Teoria do ordenamento Jurídico. Brasília : Editora da UnB, 1999.

CANCLINI, Nestor G. Diferentes, desiguais e desconectados: mapas da interculturalidade. Rio de Janeiro: UFRJ, 2006.

CANOTILHO, J. J. Gomes. Direito constitucional e teoria da constituição. Imprenta: Coimbra, Almedina, 2012

CASTRO-GÓMEZ, Santiago. La poscolonialidade explicada a los niños. Cauca : Jiga de Letras, 2005.

Declaração Universal dos Direitos da Mae Terra. (2010) From World People's Conference on Climate Change and the Rights of Mother Earth, Cochabamba, Bolivia, 22 April - Earth Day 2010. Disponível em http://www.rightsofmotherearth.com/images2015/declarations $\% 20$ pdf/declarationpo.pdf. Acesso em 19 de novembro de 2017.

DESCARTES, René. Discurso do Método. Tradução Maria Ermantina Galvão. $2^{\text {a }}$ edição. São Paulo : Martins Fontes, 2001.

DURKHEIM, Émile. Divisão do Trabalho Social II. Tradução Eduardo Brandão. 2 ${ }^{\text {a }}$ edição. Lisboa : Editorial Presença Ltda, 1987.

DWORKIN, Ronald. Império do Direito. Tradução Jefferson Luiz. $2^{a}$ edição. São Paulo: Martins Fontes, 2003. 
ESCOBAR, Arturo. Mundos y Conocimientos de outro Modo: El programa de investigación de modernidad/colonialidade latino-americano. In: Revista TABULA RASA $n^{o} 1$, enero-diciembre 2003, pp.: 51-86.

FAJARDO, Raquel Z. Yrigoyen. El pluralismo jurídico en la historia constitucional latinoamericana: de la sujeción a la descolonización. In: Seminário Pluralismo jurídico e multiculturalismo. Brasília: ESMUPE, 13 a 14 de abril de 2010. Disponível em: $<$ http://www.scribd.com/doc/194283842/3-Ryf-2010-Constitucionalismo-yPluralismoBr>. Acesso em: 14 fev. 2018.

FANON, Frans. Pele negra, máscaras brancas. Tradução de Renato da Silveira. $1^{a}$ Edição. Salvador : EDUFBA, 2008.

GUDYNAS, Eduardo y ACOSTA, Alberto. El buen viver mas allá del desarrollo. Quehacer. Lima: Desco, 2011, p. 71-73.

GUDYNAS, Eduardo. Derechos de la naturaleza, muchos protagonistas, único sujeto. Temas para el debate 195. Madrid, 2011.

HABERMAS, Jürgen. Direito e Democracia: entre facticidade e validade I e II. Tradução Flávio Beno Siebeneichler. 4ª Edição. Rio de Janeiro: Tempo Brasileiro, 1997.

HABERLE, Peter e BOFILL, Hèctor López. Poesía y Direcho Constitucional: uma conversación. Traducion Joaquín Brage Camazano Punto de vista 17. Barcelona: Fundació Carles, 2004.

HART, Herbert. O conceito de Direito. Lisboa: Fundação Caloustre Gulbenkian, 1994.

HALL, Stuart. A identidade cultural na pós-modernidade. Tradução Tomaz Tadeu da Silva, Guaracira Lopes Louro. 11ª Edição. Editora DP\&A: São Paulo, 2004.

HEGEL, G. W. F. Fenomenologia do Espírito - Parte I e II. Tradução Paulo Meneses. $2^{a}$ Edição. Petrópolis: Editora Vozes, 1992.

HERNANDEZ, Leila L. A África na sala de aula: visita à história contemporânea. São Paulo: Selo Negro, 2008.

HUANACUNI, Fernando Mamani. Buen Vivir / Vivir Bien - Filosofía, políticas, estratégias y experiências regionales andinas. Coordenación Andina de Organizaciones Indígenas - CAOI, Lima - Perú, 2010.

JAMES, Cyril Lionel Robert. Os Jacobinos negros - Toussaint L'Ouverture e a revolução de São Domingos. Tradução Afonso Teixeira Filho. $1^{\text {a }}$ Edição. São Paulo: Boitempo, 2010.

KAKOZI, Jean Bosco. Entrevista: Filosofia africana a luta pela razão e uma cosmovisão para proteger todas as formas de vida. In: https://www.sul21.com.br/ultimasnoticias/geral/2018/05/filosofia-africana-a-luta-pela-razao-e-uma-cosmovisao-paraproteger-todas-as-formas-de-vida/. Acesso em 06 de agosto de 2019. 
KELSEN, Hans. Teoria Pura do Direito. São Paulo : Martins Fontes, 1997.

KELSEN, HANS. Teoria Geral do Direito e do Estado. São Paulo : Martins Fontes, 2000 .

LATOUR, Bruno. Jamais fomos modernos: ensaio de Antropologia simétrica. Tradução Carlos Irineu da Costa. 1ª Edição. Rio de Janeiro: Ed.34, 1994.

LATOUCHE, Serge. Existirá uma vida após o desenvolvimento? Tradução Acácio Sidinei Almeida Santos. Estudos de Sociologia, Rev. do Progr. de Pós-Graduação em Sociologia da UFPE, v. 16, n. 2, 2010, p. $217-230$.

LATOUCHE, Serge. A África pode contribuir para resolver a crise do ocidente? Tradução de Maíra Albuquerque. Espaço Plural. Ano XIV, nº 28, $1^{\circ}$ Semestre, 2013, p. $175-197$

LUHMANN, Niklas. Sociologia do Direito II : Rio de Janeiro : Tempo Brasileiro, 1983.

MALDONADO-TORRES, Nelson. Sobre la colonialidad del ser: contribuciones al desarrollo de un concepto. CASTRO-GÓMEZ, Santiago \& GROSFOGUEL, Ramon (coords.) El giro decolonial: reflexiones para uma diversidad epistêmica más allá del capitalismo global. Bogotá: Siglo del Hombre Editores; Universidad Central, Instituto de Estudios Sociales Contemporáneos, Pontificia Universidad Javeriana, Instituto Pensar, 2007.

MASSUMI, Brian. O que os animais nos ensinam sobre política. Tradução: Francisco Trento, Fernanda Mello. São Paulo: n-1 edições, 2017.

MBEMBE, Achille. Crítica da razão negra. Tradução Marta Lança. $1^{a}$ Edição. Antígona : Lisboa, 2014.

MBEMBE, Achille. As Formas Africanas de Autoinscrição. Tradução Patrícia França. Revista AfroÁsia, Salvador, pp.:171-209, 2011.

MÉDICI, Alejandro. Teoría constitucional y giro decolonial: narrativas y simbolismos de las constituciones Reflexiones a propósito de la experiencia de Bolivia y Ecuador. Otros Logos. Revista de estúdios críticos. CEAPEDI, Neuquén, ano 1, n. 1, 2010, p. 94-124.

MIGNOLO, Walter. Historias locales/disenos globales: colonialidad, conocimientos subalternos y pensamiento fronterizo. Madrid: Akal, 2003.

MIGNOLO, Walter. A colonialidade de cabo a rabo: o hemisfério ocidental no horizonte conceitual da modernidade. A colonialidade do saber: eurocentrismo e ciências sociais. Perspectivas latinoamericanas. Edgardo Lander (org). Colección Sur Sur, CLACSO, Ciudad Autónoma de Buenos Aires, Argentina. setembro, 2005, p. 33-49.

MIGNOLO, Walter. La opción decolonial: desprendimiento y apertura. Um manifiesto y un caso. Tabula Rasa, n.8, 2008, p. 243-282. 
MIGNOLO, Walter. Desobediencia epistémica: retórica de la modernidad, lógica de la colonialidad y gramática de la descolonialidad. Argentina: Ediciones del signo, 2010.

MOURA, Clóvis. História do negro brasileiro. $2^{\text {a }}$ Edição. São Paulo : Editora Ática, 1992.

QUIJANO, Aníbal. "Colonialidad y Modernidad-racionalidad". In: BONILLO, Heraclio (comp.). Los conquistados. Bogotá: Tercer Mundo Ediciones; FLACSO, 1992, pp. 437449. Tradução de Wanderson Flor do Nascimento. Disponível em: https://kupdf.com/download/an-iacute-bal-quijano-colonialidade-e-modernidaderacionalidade 58d19f11dc0d60f621c346b1 pdf Colonialidade e Modernidade/Racionalidade. Acesso em 11 de abril de 2018.

QUIJANO, Aníbal. Colonialidade do poder, eurocentrismo e América Latina. A colonialidade do saber: eurocentrismo e ciências sociais. Perspectivas latinoamericanas. Edgardo Lander (org). Colección Sur Sur, CLACSO, Ciudad Autónoma de Buenos Aires, Argentina. setembro, 2005, p. 107-130.

RENAN, Ernest. O que é uma nação? In: MELLO, Renato de. A nação de Renan. Revista CALIGRAMA. Belo Horizonte, 4:139-180 - Dezembro, 1999.

ROSENFELD, Michel. A identidade do sujeito constitucional. Tradução Menelick de Carvalho Netto. $1^{\text {a }}$ Edição. Belo Horizonte: Mandamentos, 2003.

SEGALA, André William. Guerra, violência e ética: Uma análise dos conflitos bélicos pelo prisma da filosofia ocidental. Dissertação do Programa de Pós-graduação em Filosofia - PPGFIL da Universidade de Caxias do Sul, 2016.

SERRANO, Carlos. A dimensão ritual na solução de conflitos na justiça tradicional de sociedades africanas justiça tradicional de sociedades africanas. In. Revista do Centro de Estudos Africanos da Universidade de São Paulo. São Paulo. 24-25-26: 163-173, 2002/2003/2004/2005.

SPINK, M. J. Linguagem e produção de sentidos no cotidiano. Rio de Janeiro: Centro Edelstein de Pesquisas Sociais - SCIELO, 2010. Disponível em: https://static.scielo.org/scielobooks/w9q43/pdf/spink-9788579820465.pdf. Acesso em 02 de nov de 2017.

SHOHAT, Ella; STAM, Robert. Crítica da imagem eurocêntrica: multiculturalismo e representação. Tradução Marcos Soares. São Paulo: Cosac\&Naify, 2006.

SUSAN BUCK-MORSS. Hegel e Haiti. Tradução Sebastião Nascimento. Revista Novos Estudos CEBRAP 90, julho 2011 p. 131-171.

SPIVAK, Gayatri. Pode o subalterno falar? Trad. Sandra Regina Goular Almeida, Marcos Pereira Feitosa, André Pereira Feitosa. Belo Horizonte: UFMG, 2010.

VIDAL, Lux Boelitz. Mito, História e Cosmologia: as diferentes versões da guerra dos Palikur contra os Galibi entre os povos indígenas da Bacia do Uaçá, Oiapoque, Amapá. Revista de Antropologia, São Paulo, USP, V. 44 n 1, 2001, p. 117-147. 
WALLERSTEIN, I. O sistema mundial moderno. Vol. I: a agricultura capitalista e as origens da economia-mundo europeia no século XVI. Porto: Ed. Afrontamentos, 1974.

WEBER, Max. A objetividade do conhecimento nas Ciências Sociais. In: COHN, Gabriel. (Org.). WEBER, Max. Sociologia. São Paulo: Ática, 2004. (Coleção Grandes Cientistas Sociais).

WOLKMER, Antônio Carlos. Constitucionalismo e direitos sociais no Brasil. São Paulo: Acadêmica, 1989.

Recebido em: 01/07/2020 * Aprovado em: 23/09/2020 * Publicado em: 16/12/2020 